\title{
PREDICTING BOILER EFFICIENCY DETERIORATION USING ENERGY BALANCE METHOD: CASE STUDY IN 660 MW POWER PLANT JEPARA, CENTRAL JAVA, INDONESIA
}

\author{
Muhammad Sagaf ${ }^{1,}$, , Saharul Alim ${ }^{1}$, Cahya Wibisono ${ }^{2}$, Amron Muzakki ${ }^{2}$
}

\begin{abstract}
This research aims to determine the deterioration of boiler efficiency in Tanjung Jati B Unit 3 and 4 coalfired power plant with capacity 2x660 MW in Jepara Central Java Indonesia using energy balance (indirect method) based on ASME PTC 4-2018. The deterioration of boiler efficiency per year estimated using linear regression. From the results of the research, it is found that the deterioration in boiler efficiency of unit 3 is $0.19 \%$ per year and unit 4 is $0.44 \%$ per year. Large heat losses that vary for each performance test are greatly influenced by the use of various coal properties.
\end{abstract}

Keywords: Boiler Efficiency, Deterioration, Energy Balance Method, Linear Regression

\section{INTRODUCTION}

The efficiency of pulverized coal-fired power plant is influenced by design and operating parameters including operating pressure on high pressure (HP) turbine, intermediate pressure (IP) and low pressure (LP), boiler efficiency, the water content in coal, preheated air temperature, main steam temperature and reheated steam temperature [1]. In addition, the characteristic of coal can affect the efficiency, reliability, and availability of boiler and emission control part [2].

Petcoke coal which has a low reactivity compared to Indian coal can cause lower outlet furnace temperatures. Combustion can be optimized using a higher design furnace to avoid burning outside the furnace. This can cause variations in exhaust temperature which can affect the performance of the superheater and reheater [3]. The use of coal with Gross Calorie Value (GCV) will increase boiler efficiency. The ash content and moisture in coal will also have an effect on boiler efficiency. The result shows that testing using semi-bituminous coal produces an efficiency value of almost $3 \%$ because it has a higher GCV, smaller ash, and moisture content compared to Indian lignite coal which had greater ash and moisture content [4]. The high ash content of coal gives a significant impact in determining boiler design and equipment. The spread of ash by radiation near the water wall will prevent the absorption of heat in the water wall. The ash that melts at high temperatures in the furnace will catch the water wall and cause slagging. Ash particles that release heat in the convection zone will cause pipe fouling [5].

The efficiency of the boiler will have a direct effect on the generator's heat rate. Where boiler efficiency increases by $1 \%$, it will reduce the plant's heat rate by $1 \%$. In other words, to maintain the desired heat rate, boiler performance must be increased, by reducing various heat losses and controlling the flue gas temperature [6]. In addition, the performance of a power plant will decrease if operated at a partial load. [7]

A suitable method for estimating boiler efficiency due to the influence of hydrogen in coal is a linear regression method. The efficiency of the boiler has a very close relationship with hydrogen content in fuel, so this method can simplify the steps in finding boiler efficiency [8].

This research aims to determine the deterioration of boiler efficiency in Tanjung Jati B Unit 3 and 4 $(\mathrm{TJB} \# 3,4)$ coal-fired power plant with capacity $2 \times 660 \mathrm{MW}$ in Jepara Central Java Indonesia using energy balance (indirect method) based on ASME PTC 4-2018 [9].

This paper was recommended for publication in revised form by Regional Editor Hafiz Muhammad Ali

${ }^{1}$ Department of Electrics Engineering, Universitas Islam Nahdlatul Ulama, Jepara, Central Java, INDONESIA

${ }^{2}$ Department of Operation, Komipo Pembangkitan Jawa Bali, Jepara, Central Java, INDONESIA

${ }^{\star} E$-mail address: sagaf@unisnu.ac.id

Orcid id: 0000-0002-2814-0975, 0000-0002-4950-562X, 0000-0002-3778-3761, 0000-0001-6651-7262

Manuscript Received 23 October 2018, Accepted 20 February 2019 


\section{SYSTEM DESCRIPTION}

TJB \#3,4 power system has capacity of $2 \times 660$ MW with the main components boiler (steam generator), turbine, generator, primary air fan, forced draft fan, induced draft fan, chimney, boiler feed pump motor, turbine boiler feed pump, condensate feed pump, electrostatic precipitator, flue gas desulphurization.

The two Steam Generators (SG) which is one of the major parts of the coal-fired power plant is maximum continuous rating (MCR) 2,285 t/hr, with associated auxiliaries. It is fired with coal and capable to be fired with light fuel oil (LFO) for start-up, low-load, and shutdown purposes. The steam from each SG is passed to its associated steam turbine and, each of the two units can be operated completely independent of each other. The steam generator is sub-critical, drum-type design, forced circulation, top-supported, two-pass, outdoor type with single reheat and consisting of a water-cooled furnace, superheaters, reheaters, and economizers. The design lives steam parameters are 174.3 bar and $541{ }^{\circ} \mathrm{C}$ and the reheat steam parameters are 37.5 bar and $541{ }^{\circ} \mathrm{C}$. The steam generator is capable of variable pressure operation (sliding pressure).

The hot water from HP heaters enters into economizer tubes, where the water absorbs heat from the outgoing flue gas. The outlet of the economizer is connected to the bottom half of the steam drum. The water flows down from the steam drum to the boiler water circulation pump (BCP) suction manifold. The BCP circulates the water through the downcomer pipes to the water wall headers and through the furnace wall tubes to the drum. The water is converted to steam in the furnace walls by absorbing heat generated by the combustion of fuel. The steamwater mixture flows to the steam drum, where it is separated into steam and water.

The steam is further heated in the primary, secondary and tertiary superheater and then supplied to the steam turbine through main steam piping. The exhaust steam from the HP turbine flows back to the boiler through the cold reheat piping and is reheated in the reheater. The hot reheat steam is supplied to the IP turbine through hot reheat piping. The main steam temperature is controlled by two-stage attemperation, by spraying water in the desuperheater located between the primary superheater and secondary superheater, and between secondary superheater and tertiary superheater. Similarly, the reheat steam temperature is controlled to the desired value by burner tilting mechanism. However, there is a desuperheater provided at the inlet of reheater to spray water in case of emergency.

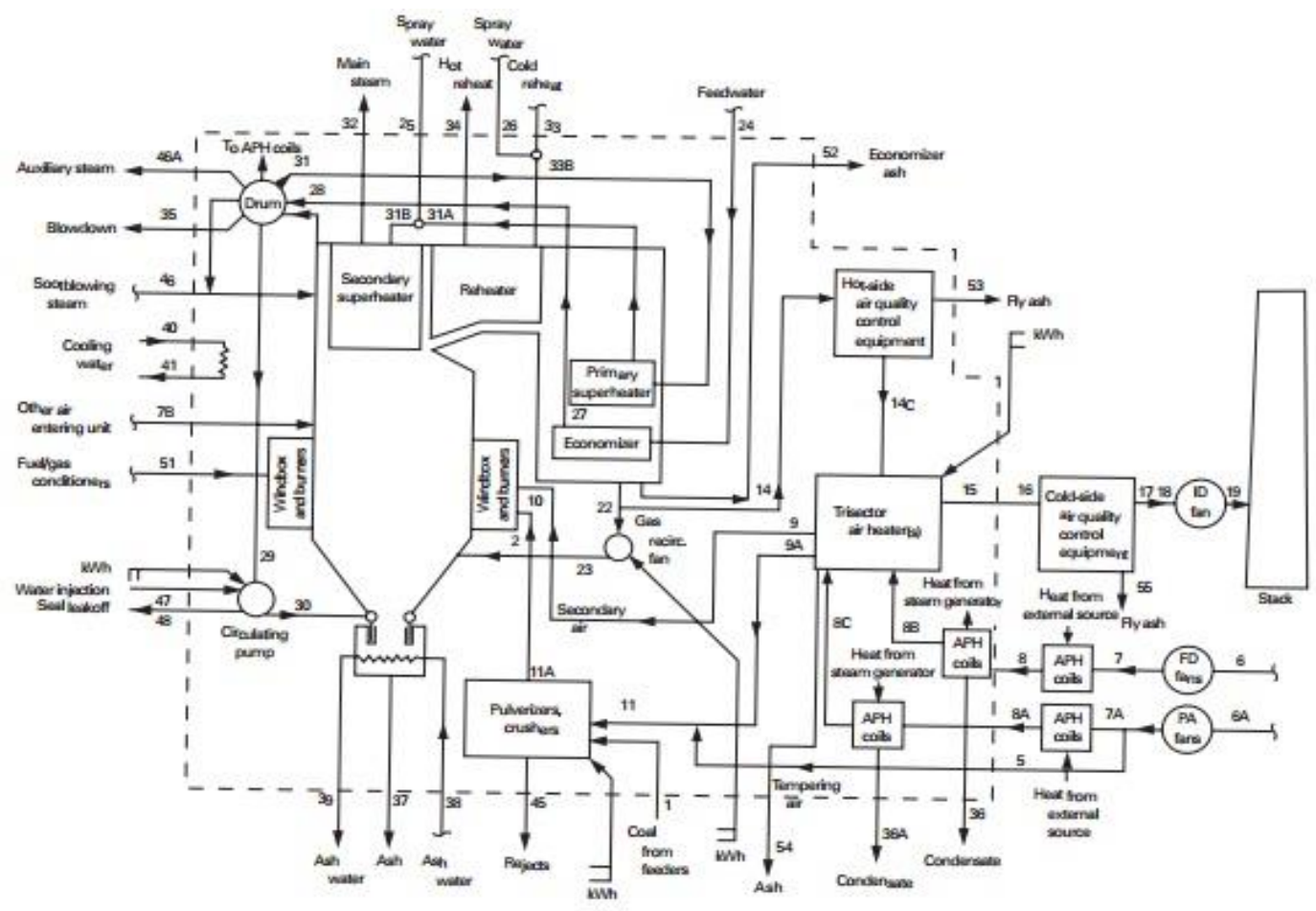

Figure 1.Typical Pulverized Coal-Fired Steam Generator with trisector Air Heater [9] 
The auxiliary steam required for the burner atomizing steam and pulverizer inert steam is supplied from the boiler tertiary SH inlet header after necessary pressure reduction. Soot blowing steam is also supplied from the tertiary SH inlet header.

A blowdown tank is provided to receive the various drains from the boiler pressure parts like economizer, water walls, steam drum, soot blower and auxiliary steam lines etc. The hot drains from blow down tank are led to the boiler drain pit after suitable attemperation.

Testing Conditions (Performance test) is carried out at 660 MW load (100\% load). Testing is carried out twice in a year and in two different periods. That are the rainy and dry periods. This is due to the weather condition, which may affect the level of water content in coal, ambient temperature, and moisture content.

In order to obtain a reliable and comparable result of the test consecutively, internal testing conditions must be carried out according to the standard. The following conditions must be done as a minimum standard when testing: boilers must be operated in automatic control mode, the turbine generator must be kept at a constant load of $660 \mathrm{MW}$ net, continuous blowdown (CBD) must not be operated during the testing process, all soot blowing process must be carried out and completed before testing and must be stopped during the test, coal silos must be filled with sufficient quantities for testing with the same coal, coal filling (coal unloading) may not be carried out during testing, each ash hopper must be emptied at least 2 hours before the test is carried out, all drain line valves must be closed.

\section{ANALYSIS}

There are two methods to calculate boiler efficiency, namely by the direct (input-output) method and indirect (heat losses/energy balance) method. In the input-output method, the addition of total heat to the working fluid in the economizer section, the evaporator, heat and reheating are calculated and the results are divided by the fuel input energy. The uncertainty of the direct method is quite large between $3 \%-6 \%$ because it is very difficult to measure the flow rate of fuel and working fluid with an accuracy of more than about $5 \%$, so this direct method is not too accurate and is not used in the calculation of boiler efficiency(EF), as defined in eq.1[9]:

$$
E F=100\left(\frac{\text { output }}{\text { Input }}\right)=100\left(\frac{Q_{r} O}{M_{r} F \times H H V F}\right)
$$

where $\mathrm{Q}_{\mathrm{r}} \mathrm{O}$ is output, $\mathrm{M}_{\mathrm{r}} \mathrm{F}$ is the measured mass flow rate of fuel, $\mathrm{HHVF}$ is higher heating value of fuel

The basic equation of EF on the energy balance method is presented in eq.2. This method has a small uncertainty between $0.4 \%-0.8 \%$, so this method is widely used in the practice of calculating boiler efficiency. In this method, it is considered that the total fuel input energy is transferred to the working fluid or lost in various ways, but this loss can be known. There are 6 kinds of heat losses in the boiler and all is calculated in the form of energy losses per unit mass of fuel $(\mathrm{kJ} / \mathrm{kg})$ or $(\mathrm{Btu} / \mathrm{lb})$.

$$
E F=\left(100-S_{m} Q_{p} L+S_{m} Q_{p} B\right)\left(\frac{Q_{r} O}{Q_{r} O+S_{m} Q_{r} L-S_{m} Q_{r} B}\right)
$$

where $S_{m} Q_{p} L$ and $S_{m} Q_{p} B$ are the sums of losses and credits calculated on percent input from fuel basis, $S_{m} Q_{r} L$ and $S_{m} Q_{r} B$ are the sum of the losses and credits calculated on Btu/hr (W) basis, or boiler efficiency $(\eta)$ can be expressed in eq.3[10]:

$$
\eta=\left[100-\left\{\frac{\left(L_{1}+L_{2}+L_{3}+L_{4}+L_{5}-B_{1}\right)}{\left(H_{f} \times 100+L_{6}\right)}\right\}\right] \times\left\{\frac{Q_{r} O}{Q_{r} O-B_{2}}\right\}
$$

where 1 is heat loss due to heat in dry gas, $L_{2}$ is heat loss due to moisture in fuel, $L_{3}$ is heat loss due to moisture from burning hydrogen in fuel, $L_{4}$ heat loss due to moisture in air, $L_{5}$ is combustible in refuse, $L_{6}$ is heat loss due to surface radiation and convection (according to ABMA chart), $H_{f}$ is fuel higher heating value, $B_{1}$ is heat credit (entering dry air, sensible heat in fuel, moisture entering with inlet air), $B_{2}$ is pulverizers, boiler circulation pump, air preheater drive power consumption, $Q_{r} O$ is boiler heat output. 
Other losses, such as losses due to unburned combustibles (unburned hydrogen and hydrocarbon, carbon monoxide), sensible heat of residue, Nox formation and radiation to bottom ash hopper and sensible heat in slag, etc. are not considered for the boiler efficiency calculation because the magnitude of the losses is negligibly small.

Heat loss due to heat in dry gas $\left(L_{1}\right)$ is presented in eq.4.

$$
L_{1}=\mathrm{M} F_{r} \mathrm{D} F_{g} \times \mathrm{HDF} F_{g} L_{v} C_{r}
$$

where $\mathrm{M} F_{r} \mathrm{D} F_{g}$ is dry gas, $\mathrm{HDF} F_{g} L_{v} C_{r}$ is enthalpy of dry gas at air heater (AH) outlet gas.

Heat loss due to moisture in fuel $\left(L_{2}\right)$ is presented in eq.5.

$$
L_{2}=\mathrm{M} F_{r} \mathrm{WF} \times \mathrm{H} W_{v} L_{v} C_{r}
$$

where $\mathrm{M} F_{r} \mathrm{WF}$ is moisture from water in fuel, $\mathrm{H} W_{v} L_{v} C_{r}$ is enthalpy of water vapor at $\mathrm{AH}$ outlet gas

Heat loss due to moisture from burning hydrogen in fuel $\left(L_{3}\right)$ is presented in eq.6.

$$
L_{3}=\mathrm{MF}_{r} \mathrm{WH}_{2} \mathrm{~F} \times \mathrm{HW}_{v} L_{v} C_{r}
$$

where $\mathrm{MF}_{r} \mathrm{WH}_{2} \mathrm{~F}$ is moisture in the combustion of hydrogen in fuel, $\times \mathrm{HW}_{v} L_{v} C_{r}$ is enthalpy of water vapor at $\mathrm{AH}$ outlet gas (hydrogen and water in the fuel are all defined to water vapor)

Heat loss due to moisture in $\operatorname{air}\left(L_{4}\right)$ is presented in eq.7.

$$
L_{4}=\mathrm{M} F_{r} \mathrm{WDA} \times \mathrm{M} F_{r} \mathrm{DA} \times \mathrm{H} W_{v} L_{v} C_{r}
$$

where $\mathrm{M} F_{r} \mathrm{WDA}$ is absolute humidity, $\mathrm{M} F_{r} \mathrm{DA}$ is dry air.

Combustible in refuse $\left(L_{5}\right)$ is presented in eq.8.

$$
L_{5}=M_{p} U_{b} \mathrm{C} \times 33700
$$

where $M_{p} U_{b} \mathrm{C}$ is unburned carbon in fuel

Heat credit $\left(B_{1}\right)$ is presented in eq.9.

$$
B_{1}=Q_{q} \mathrm{BDA}+Q_{q} \mathrm{BWA}+Q_{q} \mathrm{BF}
$$

where $Q_{q} \mathrm{BDA}$ is entering dry air, $Q_{q} \mathrm{BWA}$ is moisture entering with inlet air, $Q_{q} \mathrm{BF}$ is sensible heat in fuel.

Pulverizers, boiler circulation pump, air preheater drive power consumption $\left(B_{2}\right)$ is presented in eq. 10 .

$$
B_{2}=\mathrm{Q} X_{p u l v}+\mathrm{Q} X_{b c p}+\mathrm{Q} X_{a h}
$$

where $\mathrm{Q} X_{p u l v}$ is power consumption of pulverizer, $\mathrm{Q} X_{b c p}$ is power consumption of $\mathrm{BCP}, \mathrm{Q} X_{a h}$ is power consumption of $\mathrm{AH}$.

Boiler heat output is presented in eq. 11.

$$
Q_{r o}=\left(\left(H_{v p} \times W_{v p}\right)-\left(H_{\text {aalim }} \times W_{\text {aalim }}\right)-\left(H_{s s} \times W_{s s}\right)\right)+\left(W_{\text {vrec }} \times\left(H_{r c}-H_{r f}\right)\right)+\left(W_{r s} \times\left(H_{r c}-H_{r s}\right)\right)
$$

where $H_{v p}$ is Super Heater (SH) outlet steam enthalpy, $W_{v p}$ is main steam flow, $H_{a a l i m}$ is eco inlet water enthalpy, $W_{\text {aalim }}$ is eco inlet water flow, $W_{\text {vrec }}$ is reheat steam flow, $H_{r c}$ is Reheater $(\mathrm{RH})$ outlet steam enthalpy, $H_{r f}$ is $\mathrm{RH}$ inlet steam enthalpy, $W_{s s}$ is SH spray water flow, $H_{s S}$ SH spray water enthalpy, $W_{r s}$ is RH spray water flow, $H_{r s}$ is RH spray water enthalpy. 
Journal of Thermal Engineering, Technical Note, Vol. 6, No. 6, Special Issue 12, pp. 247-256, December, 2020

\section{RESULTS AND DISCUSSION}

Calculation of losses and boiler efficiency at 2x660 MW TJB \#3,4 Power Plant was carried out from Commercial Operation Day (COD) to the last Performance Test (PT). Table 1 and Table 2 show the parameter data for calculation. In Table 3 and Table 4, we can see losses and boiler efficiency for unit 3 and unit 4.

Boiler efficiency values vary for each performance test for both unit 3 and unit 4 boilers due to the coal properties used also vary that indicated in Table 3 and Table 4. One of the coal properties that causes boiler efficiency difference is the different calorific value of the used coal. The results of the $1^{\text {st }}$ performance test of boiler unit 3 with coal calorie $5900 \mathrm{kcal} / \mathrm{kg}$, producing boiler efficiency of $89.71 \%$, and the $10^{\text {th }}$ performance test with lower coal calorie of $5542 \mathrm{kcal} / \mathrm{kg}$ giving the efficiency of $88.38 \%$ indicated in Tables 1 and 3 . Tables 2 and Table 4 present the result of the $13^{\text {th }}$ boiler performance test obtained efficiency value of $89.08 \%$ with the calorific value of $5814 \mathrm{kcal} / \mathrm{kg}$ and lower efficiency value of $87.48 \%$ obtained from the use of coal with the calorific value 5456 $\mathrm{kcal} / \mathrm{kg}$. This is consistent with the results of previous research where the calorific value of coal will have a significant effect on boiler efficiency. The higher calorific value of coal will increase as the value of boiler efficiency.

Table 1. The parameter data of boiler unit 3

\begin{tabular}{|c|c|c|c|c|c|c|c|c|c|c|c|c|c|c|}
\hline \multirow{2}{*}{ DESCRIPTION } & \multicolumn{13}{|c|}{ TEST CONDITION VALUE } & \multirow{2}{*}{ UNIT } \\
\hline & 1 & 2 & 3 & 4 & 5 & 6 & 7 & 8 & 9 & 10 & 11 & 12 & 13 & \\
\hline Higher heating value & 5,900 & 5,455 & 5,919 & 5,841 & 5,735 & 5,806 & 5,899 & 5,723 & 5,821 & 5,542 & 5,805 & 5,551 & 5,806 & $\mathrm{kcal} / \mathrm{kg}-\mathrm{f}$ \\
\hline Carbon content (AR) & 59.38 & 57.71 & 59.11 & 56.68 & 59.38 & 59.75 & 61.08 & 60.29 & 62.17 & 58.22 & 60.43 & 58.10 & 60.08 & \multirow{7}{*}{ wt $\%$} \\
\hline Hydrogen content (AR) & 4.33 & 3.89 & 5.16 & 4.60 & 4.07 & 4.71 & 4.52 & 4.26 & 4.12 & 4.46 & 4.68 & 4.43 & 4.92 & \\
\hline Oxygen content (AR) & 13.36 & 12.56 & 11.81 & 14.85 & 12.27 & 12.04 & 13.09 & 12.20 & 10.54 & 10.83 & 11.08 & 10.79 & 11.82 & \\
\hline Sulfur content (AR) & 0.41 & 0.64 & 0.61 & 0.66 & 0.55 & 0.54 & 0.52 & 0.67 & 0.48 & 0.65 & 0.84 & 0.95 & 0.55 & \\
\hline Nitrogen content (AR) & 1.35 & 1.07 & 1.44 & 1.16 & 1.22 & 1.03 & 1.25 & 0.84 & 1.17 & 1.13 & 1.31 & 1.23 & 1.11 & \\
\hline Ash content (AR) & 6.17 & 5.52 & 5.44 & 5.18 & 4.94 & 5.89 & 3.89 & 4.79 & 5.52 & 4.39 & 5.36 & 5.00 & 2.89 & \\
\hline Moisture content (AR) & 15.00 & 18.62 & 16.44 & 16.82 & 17.57 & 16.06 & 15.65 & 16.95 & 16.00 & 20.33 & 16.29 & 19.50 & 18.63 & \\
\hline Total moisture content & 15.00 & 18.62 & 16.44 & 16.82 & 17.57 & 16.06 & 15.65 & 16.95 & 16.00 & 20.33 & 16.29 & 19.50 & 18.63 & \multirow{6}{*}{$\mathrm{wt} \%$} \\
\hline Fixed carbon content & 40.37 & 39.61 & 40.27 & 40.56 & 40.15 & 40.86 & 41.78 & 41.97 & 40.48 & 39.56 & 40.17 & 39.71 & 40.85 & \\
\hline Volatile moisture content & 38.46 & 36.25 & 37.85 & 37.44 & 39.14 & 37.20 & 38.68 & 36.30 & 38.00 & 35.73 & 38.18 & 35.79 & 37.63 & \\
\hline Ash content (AR) & 6.17 & 5.52 & 5.44 & 5.18 & 4.94 & 5.89 & 3.89 & 4.79 & 5.52 & 4.39 & 5.36 & 5.00 & 2.89 & \\
\hline Unburned carbon in fuel & 0.0000 & 0.0088 & 0.0104 & 0.0179 & 0.0125 & 0.0422 & 0.0320 & 0.0320 & 0.0513 & 0.0619 & 0.0367 & 0.0484 & 0.0408 & \\
\hline Carbon burned content & 59.37 & 57.70 & 59.10 & 56.66 & 59.37 & 59.71 & 61.05 & 60.26 & 62.12 & 58.15 & 60.39 & 58.05 & 60.04 & \\
\hline $\mathrm{AH} \mathrm{O} 2$ in dry flue gas & 3.40 & 3.32 & 3.79 & 3.60 & 3.45 & 2.05 & 2.14 & 1.85 & 3.77 & 2.56 & 2.43 & 1.56 & 1.86 & \multirow{2}{*}{$\%$} \\
\hline Unburned carbon in fly ash & 0.10 & 0.16 & 0.19 & 0.35 & 0.25 & 0.71 & 0.82 & 0.66 & 0.92 & 1.39 & 0.68 & 0.96 & 1.39 & \\
\hline $\begin{array}{l}\text { Ambient air temperature } \\
\text { (dry bulb) }\end{array}$ & 32.30 & 31.06 & 32.00 & 31.10 & 29.20 & 30.16 & 32.60 & 30.00 & 31.31 & 32.00 & 30.28 & 31.11 & 29.67 & \\
\hline Absolute humidity & 0.02 & 0.02 & 0.02 & 0.02 & 0.02 & 0.02 & 0.02 & 0.02 & 0.02 & 0.03 & 0.02 & 0.02 & 0.02 & $\mathrm{~kg} / \mathrm{kg}$-da \\
\hline $\begin{array}{l}\text { Temperature of } \mathrm{AH} \text { inlet } \\
\text { secondary air }\end{array}$ & 36.20 & 38.86 & 39.10 & 38.64 & 37.24 & 37.54 & 39.39 & 37.81 & 39.56 & 38.09 & 38.19 & 39.01 & 37.85 & \multirow{4}{*}{${ }^{\circ} \mathrm{C}$} \\
\hline $\begin{array}{l}\mathrm{AH} \text { inlet tempering air }(\mathrm{AH} \\
\text { inlet 1ry air) temp }\end{array}$ & 48.30 & 50.61 & 50.77 & 50.48 & 48.93 & 49.79 & 51.20 & 49.88 & 51.35 & 50.13 & 50.33 & 51.49 & 50.34 & \\
\hline $\begin{array}{l}\text { Air preheater inlet gas } \\
\text { temperature }\end{array}$ & 377.60 & 390.49 & 380.46 & 371.77 & 388.48 & 386.24 & 385.01 & 377.85 & 389.07 & 381.41 & 381.14 & 387.96 & 380.48 & \\
\hline $\mathrm{AH}$ outlet gas temperature & 142.70 & 144.78 & 143.76 & 139.78 & 146.63 & 148.42 & 151.86 & 147.73 & 148.56 & 144.99 & 148.14 & 149.80 & 145.74 & \\
\hline
\end{tabular}

The use of lignite coal with the calorific value $4300 \mathrm{kcal} / \mathrm{kg}$ will give the efficiency of $77.51 \%$ compared to semibituminous coal with the calorific value $5800 \mathrm{kcal} / \mathrm{kg}$ producing $80.20 \%$ boiler efficiency[4]. Moisture in coal is also the main parameter that gives effect to the efficiency of the pulverized coal-fired power plants [1]. From Tables 1 and Tables 3, moisture in fuel at boiler unit 3 test performance at $15.00 \%$ gives in the efficiency of $89.71 \%$, while in the 
Journal of Thermal Engineering, Technical Note, Vol. 6, No. 6, Special Issue 12, pp. 247-256, December, 2020

$10^{\text {th }}$ performance test with greater moisture of $20.33 \%$ decreased efficiency to $88.36 \%$. The effect of moisture in the fuel on boiler unit 4 is shown in Tables 2 and Tables 4, where coal with moisture in fuel of $16.79 \%$ resulting in the efficiency of $89.08 \%$ at the $13^{\text {th }}$ performance test, while moisture in fuel $23.23 \%$ causing a decrease in efficiency to $88.18 \%$.

Table 2. The parameter data of boiler unit 4

\begin{tabular}{|c|c|c|c|c|c|c|c|c|c|c|c|c|c|c|}
\hline \multirow{2}{*}{ DESCRIPTION } & \multicolumn{13}{|c|}{ TEST CONDITION VALUE } & \multirow{2}{*}{ UNIT } \\
\hline & 1 & 2 & 3 & 4 & 5 & 6 & 7 & 8 & 9 & 10 & 11 & 12 & 13 & \\
\hline Higher heating value & 5,360 & 5,266 & 5,650 & 5,600 & 5,553 & 5,618 & 5,258 & 5,906 & 5,469 & 5,456 & 5,352 & 5,879 & 5,814 & $\mathrm{kcal} / \mathrm{kg}-\mathrm{f}$ \\
\hline Carbon content (AR) & 54.39 & 57.73 & 57.27 & 56.92 & 57.82 & 58.48 & 57.07 & 61.69 & 56.60 & 57.23 & 55.40 & 60.31 & 59.48 & \multirow{7}{*}{ wt $\%$} \\
\hline Hydrogen content (AR) & 3.93 & 4.11 & 3.95 & 4.02 & 4.31 & 4.70 & 3.94 & 5.54 & 4.82 & 5.27 & 4.27 & 4.61 & 4.53 & \\
\hline Oxygen content (AR) & 13.78 & 12.35 & 12.70 & 12.07 & 11.42 & 12.51 & 9.95 & 12.22 & 12.51 & 11.91 & 11.44 & 12.54 & 13.06 & \\
\hline Sulfur content (AR) & 0.37 & 0.50 & 0.36 & 0.66 & 0.53 & 0.57 & 0.47 & 0.38 & 0.46 & 0.52 & 0.47 & 0.45 & 0.61 & \\
\hline Nitrogen content (AR) & 1.19 & 1.19 & 1.24 & 1.31 & 0.98 & 1.04 & 0.79 & 1.25 & 1.30 & 1.25 & 1.13 & 1.18 & 1.28 & \\
\hline Ash content (AR) & 5.04 & 5.80 & 5.07 & 7.01 & 3.73 & 4.48 & 5.06 & 3.51 & 3.57 & 6.72 & 4.07 & 4.01 & 4.26 & \\
\hline Moisture content (AR) & 21.30 & 18.31 & 19.41 & 18.01 & 21.23 & 18.24 & 22.72 & 15.96 & 21.72 & 18.43 & 23.23 & 16.92 & 16.79 & \\
\hline Total moisture content & 21.30 & 18.31 & 19.41 & 18.01 & 21.23 & 18.24 & 22.72 & 15.96 & 21.72 & 18.43 & 23.23 & 16.92 & 16.79 & \multirow{6}{*}{ wt $\%$} \\
\hline Fixed carbon content & 37.77 & 39.88 & 39.99 & 38.08 & 38.98 & 39.42 & 38.08 & 42.47 & 39.64 & 39.49 & 38.32 & 41.86 & 41.18 & \\
\hline Volatile moisture content & 35.89 & 36.01 & 35.53 & 36.89 & 36.06 & 37.87 & 34.14 & 38.06 & 35.07 & 35.36 & 34.38 & 37.21 & 37.77 & \\
\hline Ash content (AR) & 5.04 & 5.80 & 5.07 & 7.01 & 3.73 & 4.48 & 5.06 & 3.51 & 3.57 & 6.72 & 4.07 & 4.01 & 4.26 & \\
\hline Unburned carbon in fuel & 0.0458 & 0.0994 & 0.1627 & 0.0685 & 0.0067 & 0.1425 & 0.0408 & 0.1305 & 0.0689 & 0.2592 & 0.0806 & 0.1118 & 0.0528 & \\
\hline Carbon burned content & 54.34 & 57.63 & 57.11 & 56.86 & 57.82 & 58.34 & 57.03 & 61.56 & 56.53 & 56.97 & 55.32 & 60.19 & 59.43 & \\
\hline $\mathrm{AH} \mathrm{O} 2$ in dry flue gas & 4.21 & 3.90 & 3.37 & 3.91 & 3.09 & 2.38 & 2.92 & 2.60 & 2.54 & 2.28 & 2.90 & 2.33 & 2.03 & \multirow{2}{*}{$\%$} \\
\hline Unburned carbon in fly ash & 0.90 & 1.69 & 3.11 & 0.97 & 0.18 & 3.08 & 0.80 & 3.58 & 1.90 & 3.71 & 1.94 & 2.71 & 1.22 & \\
\hline $\begin{array}{l}\text { Ambient air temperature } \\
\text { (dry bulb) }\end{array}$ & 33.70 & 31.89 & 31.52 & 30.82 & 30.40 & 30.94 & 30.11 & 29.67 & 28.11 & 30.92 & 30.24 & 30.20 & 32.22 & \\
\hline Absolute humidity & 0.02 & 0.02 & 0.02 & 0.02 & 0.02 & 0.02 & 0.02 & 0.02 & 0.02 & 0.02 & 0.02 & 0.02 & 0.02 & $\mathrm{~kg} / \mathrm{kg}-\mathrm{da}$ \\
\hline $\begin{array}{l}\text { Temperature of } \mathrm{AH} \text { inlet } \\
\text { secondary air }\end{array}$ & 37.80 & 39.61 & 39.10 & 37.86 & 38.61 & 40.26 & 38.10 & 37.48 & 36.52 & 39.58 & 38.76 & 39.67 & 41.09 & \multirow{4}{*}{${ }^{\circ} \mathrm{C}$} \\
\hline $\begin{array}{l}\mathrm{AH} \text { inlet tempering air }(\mathrm{AH} \\
\text { inlet 1ry air) temp }\end{array}$ & 49.40 & 51.59 & 50.94 & 49.57 & 50.50 & 52.01 & 50.28 & 49.05 & 47.99 & 51.35 & 50.54 & 50.92 & 52.34 & \\
\hline $\begin{array}{l}\text { Air preheater inlet gas } \\
\text { temperature }\end{array}$ & 365.70 & 370.84 & 370.01 & 365.98 & 387.69 & 389.06 & 394.52 & 389.94 & 395.10 & 376.78 & 388.52 & 394.19 & 316.86 & \\
\hline AH outlet gas temperature & 133.70 & 138.01 & 135.21 & 138.41 & 143.34 & 146.55 & 144.85 & 144.71 & 142.96 & 143.70 & 141.46 & 148.43 & 397.69 & \\
\hline
\end{tabular}

Table 3. Losses and efficiency boiler unit 3

\begin{tabular}{|c|c|c|c|c|c|c|c|c|c|c|c|c|c|}
\hline \multirow{2}{*}{ Year } & \multirow{2}{*}{$\begin{array}{l}2011 \\
C O D \\
\end{array}$} & \multicolumn{2}{|c|}{2012} & \multicolumn{2}{|c|}{2013} & \multicolumn{2}{|c|}{2014} & \multicolumn{2}{|c|}{2015} & \multicolumn{2}{|c|}{2016} & \multicolumn{2}{|c|}{2017} \\
\hline & & $1^{\text {st }}$ & $2^{\text {nd }}$ & $1^{\text {st }}$ & $2^{\text {nd }}$ & $1^{\text {st }}$ & $2^{\text {nd }}$ & $1^{\text {st }}$ & $2^{\text {nd }}$ & $1^{\text {st }}$ & $2^{\text {nd }}$ & $1^{\text {st }}$ & $2^{\text {nd }}$ \\
\hline Number of PT & 1 & 2 & 3 & 4 & 5 & 6 & 7 & 8 & 9 & 10 & 11 & 12 & 13 \\
\hline L1 (\%) & 4.89 & 5.24 & 5.16 & 4.66 & 5.18 & 4.96 & 5.08 & 4.92 & 5.54 & 5.04 & 5.12 & 4.98 & 4.86 \\
\hline L2 (\%) & 1.63 & 2.19 & 1.78 & 1.84 & 1.97 & 1.78 & 1.71 & 1.90 & 1.77 & 2.35 & 1.80 & 2.26 & 2.06 \\
\hline L3 (\%) & 4.20 & 4.09 & 4.99 & 4.49 & 4.07 & 4.65 & 4.41 & 4.27 & 4.07 & 4.60 & 4.63 & 4.58 & 4.86 \\
\hline L4 (\%) & 0.15 & 0.18 & 0.18 & 0.18 & 0.20 & 0.15 & 0.16 & 0.20 & 0.18 & 0.24 & 0.22 & 0.21 & 0.18 \\
\hline L5 (\%) & 0.01 & 0.01 & 0.01 & 0.02 & 0.02 & 0.06 & 0.04 & 0.05 & 0.07 & 0.09 & 0.05 & 0.07 & 0.06 \\
\hline L6 (\%) & 0.19 & 0.19 & 0.19 & 0.19 & 0.19 & 0.19 & 0.19 & 0.19 & 0.19 & 0.19 & 0.19 & 0.19 & 0.19 \\
\hline B1 (kg/kg-fuel) & 147.83 & 164.78 & 185.43 & 166.10 & 152.36 & 150.85 & 173.25 & 151.00 & 189.57 & 162.23 & 164.03 & 160.92 & 155.19 \\
\hline$B 2(G J / h)$ & 10.47 & 10.70 & 10.68 & 10.59 & 10.75 & 10.43 & 10.29 & 10.14 & 10.04 & 11.02 & 10.54 & 10.45 & 9.85 \\
\hline Qro (GJ/h) & 5510.93 & 5589.31 & 5517.97 & 5556.44 & 5603.23 & 5589.56 & 5650.30 & 5590.45 & 5606.28 & 5609.69 & 5670.64 & 5576.90 & 5565.27 \\
\hline$n(\%)$ & 89.71 & 88.99 & 88.61 & 89.46 & 89.19 & 89.00 & 89.27 & 89.27 & 89.12 & 88.36 & 88.83 & 88.57 & 88.59 \\
\hline
\end{tabular}


Journal of Thermal Engineering, Technical Note, Vol. 6, No. 6, Special Issue 12, pp. 247-256, December, 2020

Table 4. Losses and efficiency boiler unit 4

\begin{tabular}{|c|c|c|c|c|c|c|c|c|c|c|c|c|c|}
\hline \multirow{2}{*}{ Year } & \multicolumn{2}{|c|}{2012} & \multicolumn{2}{|c|}{2013} & \multicolumn{2}{|c|}{2014} & \multicolumn{2}{|c|}{2015} & \multicolumn{2}{|c|}{2016} & \multicolumn{2}{|c|}{2017} & \multirow{2}{*}{$\begin{array}{c}2018 \\
1^{\text {st }} \\
\end{array}$} \\
\hline & COD & $1^{\text {st }}$ & $1^{\text {st }}$ & $2^{\text {nd }}$ & $1^{\text {st }}$ & $2^{\text {nd }}$ & $1^{\text {st }}$ & $2^{\text {nd }}$ & $1^{\text {st }}$ & $2^{\text {nd }}$ & $1^{\text {st }}$ & $2^{\text {nd }}$ & \\
\hline Number of PT & 1 & 2 & 3 & 4 & 5 & 6 & 7 & 8 & 9 & 10 & 11 & 12 & 13 \\
\hline L1 (\%) & 4.75 & 5.22 & 4.54 & 4.87 & 5.03 & 5.01 & 5.24 & 5.11 & 4.91 & 5.00 & 4.88 & 4.97 & 5.07 \\
\hline L2 (\%) & 2.53 & 2.22 & 2.19 & 2.05 & 2.45 & 2.08 & 2.77 & 1.73 & 2.54 & 2.16 & 2.77 & 1.85 & 1.86 \\
\hline L3 (\%) & 4.17 & 4.44 & 3.97 & 4.10 & 4.43 & 4.79 & 4.29 & 5.37 & 5.04 & 5.53 & 4.56 & 4.50 & 4.49 \\
\hline L4 (\%) & 0.17 & 0.18 & 0.17 & 0.18 & 0.15 & 0.20 & 0.14 & 0.14 & 0.17 & 0.17 & 0.18 & 0.19 & 0.16 \\
\hline L5 (\%) & 0.07 & 0.15 & 0.23 & 0.10 & 0.01 & 0.20 & 0.06 & 0.18 & 0.10 & 0.38 & 0.12 & 0.15 & 0.07 \\
\hline \begin{tabular}{|l|} 
L6 (\%) \\
\end{tabular} & 0.19 & 0.19 & 0.19 & 0.19 & 0.19 & 0.19 & 0.19 & 0.19 & 0.19 & 0.19 & 0.19 & 0.19 & 0.19 \\
\hline B1 (kg/kg-fuel) & 159.51 & 180.47 & 167.63 & 159.48 & 162.96 & 177.21 & 153.80 & 160.04 & 134.35 & 170.31 & 157.49 & 171.89 & 182.58 \\
\hline B2 (GJ/h) & 11.11 & 10.51 & 11.20 & 10.98 & 10.83 & 11.00 & 11.08 & 10.78 & 11.10 & 10.95 & 10.75 & 10.29 & 10.68 \\
\hline Qro (GJ/h) & 5515.52 & 5510.46 & 5459.65 & 5513.53 & 5496.88 & 5498.02 & 5506.91 & 5467.85 & 5502.93 & 5554.52 & 5533.27 & 5541.61 & 5552.22 \\
\hline$n(\%)$ & 89.01 & 88.59 & 89.61 & 89.37 & 88.62 & 88.45 & 88.19 & 88.10 & 87.81 & 87.48 & 88.18 & 89.01 & 89.08 \\
\hline
\end{tabular}

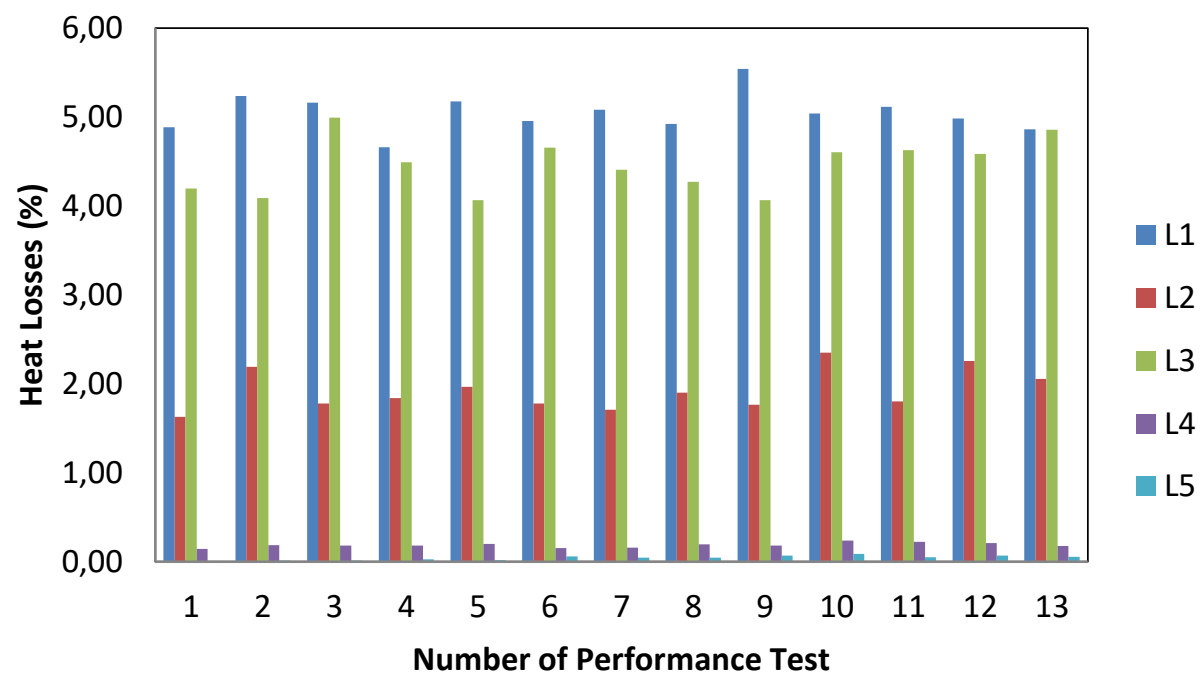

Figure 2. Heat losses and efficiency of boiler unit 3

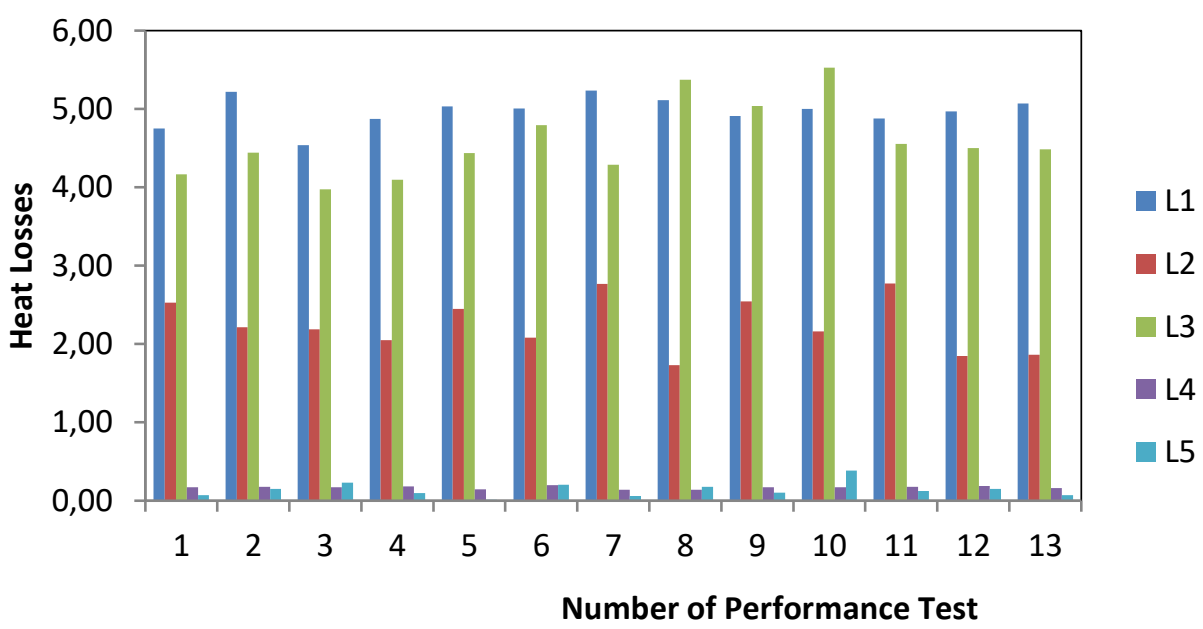

Figure 3. Heat losses and efficiency of boiler unit 4

From Figures 3 and Figures 4 it is shown that the biggest heat losses are heat loss due to heat in dry gas $\left(L_{1}\right)$, heat loss due to moisture from burning hydrogen in fuel $\left(L_{3}\right)$, heat loss due to moisture in fuel $\left(L_{2}\right)$, heat loss 
due to moisture in air $\left(L_{4}\right)$, and combustible in refuse $\left(L_{5}\right)$, but on $8^{\text {th }}, 9^{\text {th }}$, and $10^{\text {th }}$ performance test unit 4 it looks heat loss due to moisture from burning hydrogen in fuel $\left(L_{3}\right)$ greater than the heat loss due to heat in dry gas $\left(L_{1}\right)$, this is due to the hydrogen content $(\mathrm{H})$ in coal is quite large. This is in line with the previous research that the value of boiler efficiency is affected by the hydrogen content in the fuel. The higher of heat loss due to moisture from burning hydrogen in fuel $\left(L_{3}\right)$ will reduce boiler efficiency [8].

The deterioration of boiler efficiency is calculated using linear regression method [8]. Figure 4 shows the linear regression method is only used in $4^{\text {th }} \sim 13^{\text {th }}$ performance tests for boiler unit 3 , due to the $1^{\text {st }} \sim 3^{\text {rd }}$ performance test have significant deviation. Whereas in Figure 5, is only used for $3^{\text {rd }} \sim 10^{\text {th }}$ performance tests due to $1^{\text {st }}, 2^{\text {nd }}, 11^{\text {th }}, 12^{\text {th }}$ and $13^{\text {th }}$ performance also have a significant deviation. From the calculation results, it is found that the deterioration of boiler efficiency for boiler unit 3 is $0.09 \%$ per 6 months or $0.19 \%$ per year and the deterioration of boiler efficiency for boiler unit 4 is $0.22 \%$ per 6 months or $0.44 \%$ per year.

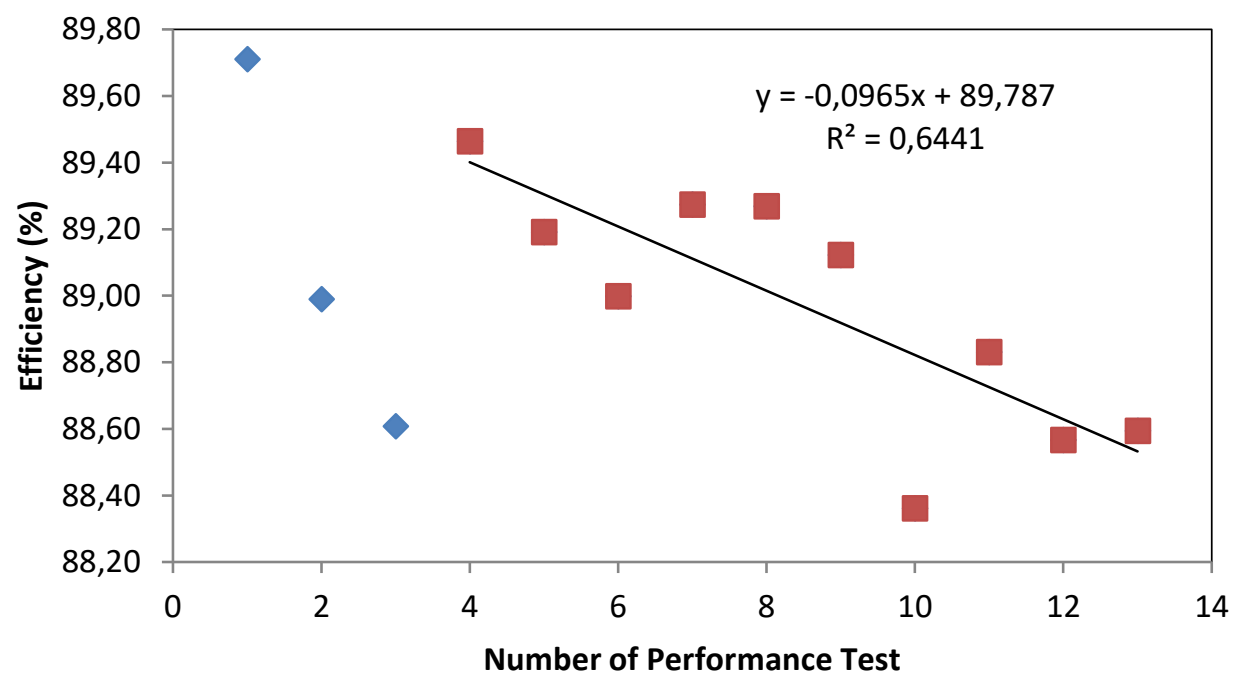

Figure 4. The deterioration of boiler efficiency unit 3

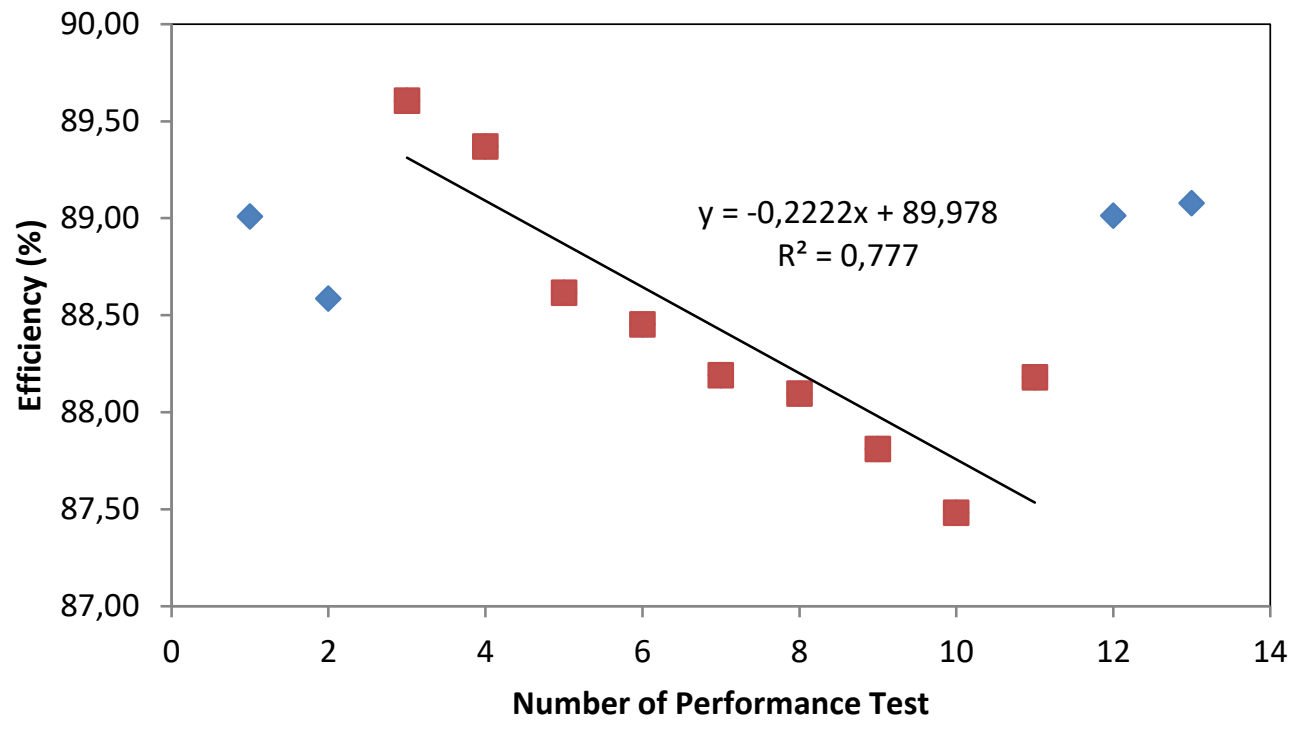

Figure 5. The deterioration of boiler efficiency unit 4 


\section{CONCLUSION}

The deterioration of boiler efficiency in Tanjung Jati B Unit 3 and 4 is successfully described using an indirect method. The results of this study indicate that the biggest heat losses are heat loss due to heat in dry gas $\left(L_{1}\right)$, heat loss due to moisture from burning hydrogen in fuel $\left(L_{3}\right)$, heat loss due to moisture in fuel $\left(L_{2}\right)$, heat loss due to moisture in air $\left(L_{4}\right)$, and combustible in refuse $\left(L_{5}\right)$. The deterioration of boiler efficiency is $0.19 \%$ per year for units 3 and $0.44 \%$ per year for units 4 . Variations in boiler efficiency values for each performance test caused by coal properties used also vary. The cause of deterioration in boiler efficiency is the use of varying quality coal and the accumulation of ash in the economizer which reduces heat transfer. It can be shown in $1^{\text {st }}$ and $3^{\text {rd }}$ performance tests of unit 3 boiler that gives us the conclusion that with the same calorific value produces much different efficiency value, due to the others coal properties are different.

\section{ACKNOWLEDGMENTS}

This research is support by DIPA Direktorat Jenderal Penguatan Riset dan Pengembangan, Kementrian Riset, Teknologi dan Pendidikan Tinggi Indonesia (DRPM RISTEKDIKTI) number DIPA-042.06.1.401516/2018. The process data were taken with permission from General Manager Pembangkit Listrik Negara (PLN) Tanjung Jati B, Jepara, Central Java, Indonesia.

\section{NOMENCLATURE}

$B_{1} \quad$ Heat credit (entering dry air, sensible heat in fuel, moisture entering with inlet air) $[\mathrm{kJ} / \mathrm{kg}$-fuel]

$B_{2} \quad$ Pulverizers, boiler circulation pump, air preheater drive power consumtion $[\mathrm{kJ} / \mathrm{hr}]$

EF $\quad$ Efficiency [\%]

$H_{\text {aalim }} \quad$ Eco inlet water enthalpy $[\mathrm{kJ} / \mathrm{h}]$

$\mathrm{HDF}_{g} L_{v} C_{r} \quad$ Enthalphy of dry gas at air heater $(\mathrm{AH})$ outlet gas $[\mathrm{kJ} / \mathrm{kg}]$

$H_{f}$ HHVF

$H_{r c}$

$H_{r f}$

$H_{r s}$

$H_{S S}$

$H_{v p}$ Fuel higher heating value $[\mathrm{kJ} / \mathrm{kg}$-fuel]

Higher heating value of fuel $[\mathrm{J} / \mathrm{kg}]$

Reheater $(\mathrm{RH})$ outlet steam enthalpy $[\mathrm{kJ} / \mathrm{h}]$

$\mathrm{RH}$ inlet steam enthalpy $[\mathrm{kJ} / \mathrm{h}]$

RH spray water enthalpy $[\mathrm{kJ} / \mathrm{h}]$

SH spray water enthalpy $[\mathrm{kJ} / \mathrm{h}]$

Super Heater (SH) outlet steam enthalpy $[\mathrm{kJ} / \mathrm{h}]$

$\mathrm{H} W_{v} L_{v} C_{r}$

$L_{1}$

$L_{2}$

$L_{3}$

$L_{4}$

$L_{5}$

$L_{6}$

$\mathrm{M} F_{r} \mathrm{DA}$

$\mathrm{M} F_{r} \mathrm{D} F_{g}$

Enthalpy of water vapor at $\mathrm{AH}$ outlet gas (hydrogen and water in the fuel is all defined to water vapor) $[\mathrm{kJ} / \mathrm{kg}]$

$\mathrm{M} F_{r} \mathrm{WDA}$

Heat loss due to heat in dry gas [kJ/kg-fuel], [\%]

Heat loss due to moisture in fuel [kJ/kg-fuel], [\%]

Heat loss due to moisture from burning hidrogen in fuel [kJ/kg-fuel], [\%]

Heat loss due to moisture in air [kJ/kg-fuel], [\%]

Combustible in refuse $[\mathrm{kJ} / \mathrm{kg}$-fuel], [\%]

Heat loss due to surface radiation and convection (according to ABMA chart) [\%]

Dry air $[\mathrm{kg} / \mathrm{kg}$-fuel $]$

Dry gas $[\mathrm{kg} / 104 \mathrm{~kJ}]$

$\mathrm{M} F_{r} \mathrm{WF}$

Absolute humidity [kg/kg-dry air]

$\mathrm{MF}_{r} \mathrm{WH}_{2} \mathrm{~F}$

Moisture from water in fuel [ $\mathrm{kg} / \mathrm{kg}$-fuel]

$M_{p} U_{b} \mathrm{C}$

Moisture in combustion of hidrogen in fuel [kg/kg-fuel]

$M_{r} F$

Unburned carbon in fuel [kJ/kg-fuel]

$Q_{q} \mathrm{BDA}$

Measured mass flow rate of fuel $[\mathrm{kg} / \mathrm{s}]$

$Q_{q} \mathrm{BF}$

Entering dry air [kJ/kg-fuel]

Sensible heat in fuel $[\mathrm{kJ} / \mathrm{kg}$-fuel] 
Journal of Thermal Engineering, Technical Note, Vol. 6, No. 6, Special Issue 12, pp. 247-256, December, 2020

$\begin{array}{ll}Q_{q} \mathrm{BWA} & \text { Moisture entering with inlet air }[\mathrm{kJ} / \mathrm{kg} \text {-fuel] } \\ Q_{r} O & \text { Boiler heat output }[\mathrm{kJ} / \mathrm{hr}] \\ \mathrm{Q} X_{a h} & \text { Power consumption of AH [GJ/h] } \\ \mathrm{Q} X_{b c p} & \text { Power consumption of BCP [GJ/h] } \\ \mathrm{Q} X_{\text {pulv }} & \text { Power consumption of pulverizer }[\mathrm{GJ} / \mathrm{h}] \\ S_{m} Q_{p} L & \text { Sum of losses [\%] } \\ S_{m} Q_{p} B & \text { Sum of credits [\%] } \\ S_{m} Q_{r} L & \text { Sum of the losses }[\mathrm{Btu} / \mathrm{hr}] \\ S_{m} Q_{r} B & \text { Sum of credits }[\mathrm{Btu} / \mathrm{hr}] \\ W_{\text {aalim }} & \text { Eco inlet water flow }[\mathrm{kg} / \mathrm{h}] \\ W_{r s} & \text { RH Spray water flow }[\mathrm{kg} / \mathrm{h}] \\ W_{s s} & \text { SH Spray water flow }[\mathrm{kg} / \mathrm{h}] \\ W_{v p} & \text { Main steam flow }[\mathrm{kg} / \mathrm{h}] \\ W_{v r e c} & \text { Reheat steam flow }[\mathrm{kg} / \mathrm{h}] \\ \eta & \text { Efficiency [\%] }\end{array}$

\section{REFERENCES}

[1] T. Sanpasertparnich and A. Aroonwilas, "Simulation and optimization of coal-fired power plants," Energy Procedia, vol. 1, no. 1, pp. 3851-3858, 2009, doi: https://doi.org/10.1016/j.egypro.2009.02.187.

[2] P. K. C. Ashok Sarkar, Prabhansu, Abhijit Chatterjee, Anup Kumar Sadhukhan. J, "Establishing correct coal quality for achieving optimum boiler efficiency \& performance - a case study in the Indian utility industry," Int. J. ChemTech Res., vol. 10, no. 2, pp. 121-131, 2017.

[3] J. Jaygopal, K. Ganesh Palappan, M. Rajavel, P. S. Guruchandran, and S. Suresh, Comparison of combustion characteristics of Petcoke and Indian sub bituminous coal in a CFB Test facility, vol. 7. 2017.

[4] V. K. P. Chetan T. Patel, Dr.Bhavesh K. patel, "Efficiency With Different Gev Of Coal And Efficiency Improvement Opportunity In Boiler,” Int. J. Innov. Res. Sci. Eng. Technol., vol. 2, no. 5, pp. 1518-1527, 2013.

[5] K. R. B. Harikrishnan S.Pillai, P. S.Seshadri, "Effect on Performance of Utility Boiler with Variation in Fuel Properties," Int. J. Appl. Eng. Res., vol. 11, no. 6, pp. 3786-3790, 2016.

[6] P. J. D. Acharya Chirag, Prof. Nirvesh Mehta, "Research paper on Analysis of Boiler losses to improve Unit heat rate of coal fired thermal power plant," Int. J. Adv. Eng. ing Res. Dev., vol. 1, no. 5, pp. 1-6, 2014.

[7] A. S. KARAKURT and U. Gunes, "Performance Analysis of a Steam Turbine Power Plant at Part Load Conditions," J. Therm. Eng., vol. 3, pp. 1121-1128, Apr. 2017, doi: 10.18186/thermal.298611.

[8] C. C. L., D. S. Jangamshetti, and S. Sonoli, "Boiler efficiency estimation from hydrogen content in fuel," in 2015 International Conference on Advances in Computing, Communications and Informatics (ICACCI), 2015, pp. 1107-1110, doi: 10.1109/ICACCI.2015.7275758.

[9] T. A. S. of M. Engineers., Fired Steam Generators Performance Test Codes 4. 2008.

[10] L. Mitsubishi Heavy Industries, "Performance Test Procedure for Boiler Thermal Efficiency." 2011. 